\title{
TAFSIR SOSIAL DALAM PRESPEKTIF AL QUR'AN
}

\author{
Ahmad Ari Masyhuri \\ Universitas Pamulang (UNPAM) \\ arymasyhuri@gmail.com
}

\begin{abstract}
Abstrak
Dialektika antara teks al-Qur'an dengan realitas sosialnya mengalami perubahan pasca Rasulullah wafat. Dampak dari perubahan ini antara lain hubungan dialog yang telah dibangun oleh al-Qur'an pada masa turunnya berubah menjadi monologis. Artinya, al-Qur'an sudah tidak lagi aktif berdialog tetapi sebaliknya menunggu untuk diajak berdialog atau cenderung dipahami secara doktrinal. Beragam diskursus, peristiwa dan konteks yang melingkupi turunnya al-Qur'an tidak akan terulang sama persis pada saat ini. Kondisi sosial kehidupan Nabi Muhammad SAW., menerima wahyu sekaligus cara beliau menafsirkannya dan mengaplikasikannya dalam sebuah prilaku juga tidak akan dapat dirasakan oleh umat Islam sekarang dan masa yang akan datang. Fakta ini menunjukkan bahwa ada rentang waktu yang sangat panjang antara al-Qur'an sekaligus nabi Muhammad dengan umat Islam yang hidup dalam dunia modern sekarang. Sehingga menjadi tantangan yang harus dihadapi para mufassir tentang perkembangan kajian teoritis tafsir sosial, sehingga mereka dapat menjelaskan dan mengungkapkan maksud serta kandungan makna al-Qur'an yang telah diwahyukan pada masa lalu tetapi harus tetap bisa dijadikan pedoman hidup sampai akhir masa.
\end{abstract}

Kata Kunci: Wahyu, Mufassir, tafsir dan Realitas Sosial

\section{Pendahuluan}

$\mathbf{K}$

eberadaan teks dalam tradisi keagamaan telah membawa implikasi besar bagi perkembangan intelektual, kebudayaan dan peradaban sosial Tradisi Arab-Islam memiliki tradisi teks yang kuat dibanding dengan peradaban yang lain atau biasa diistilahkan dengan peradaban teks yaitu suatu peradaban yang menegakkan asas- asas epistemologi dan tradisinya pada teks atau yang tidak mungkin mengabaikan peranan teks di dalamnya. ${ }^{1}$

Al-Qur'an, sebagai teks keagamaan, memiliki peran sosial budaya yang tidak dapat diabaikan dalam membentuk wajah peradaban sosial dan sekaligus menentukan watak ilmu-ilmunya. Menurut Nashr Hâmid, apabila keberadaan teks merupakan poros dari sebuah peradaban, maka upaya interpretasi yang merupakan sisi lain dari teks menjadi salah satu mekanisme budaya dan peradaban yang terpenting dalam memproduksi sebuah pengetahuan. Artinya, pada dasarnya bukanlah teks yang membangun peradaban tetapi cara manusia berdialog dengan

${ }^{1}$ Nashr Hâmid Abû Zaid, Mafhûm al-NashshDirâsah fî̀ 'Ulûm al-Qur'ân, (Beirût: Markaz al-Tsaqafî al-Arabî, 1994 M), 9 
teks di satu pihak serta dialektikanya dengan realitas di pihak lain. ${ }^{2}$ Penjelasan ini menunjukkan adanya keterkaitan antara interpretasi atau tafsir, teks al-Qur'an dengan realitas sosial masyarakat. Tulisan ini akan menjelaskan Teori-Teori Tafsir Tentang Perkembangan Kajian Teoritis Tafsir Sosial, bahwa keberadaan tafsir adalah sebagai penghubung antara teks dengan realitas. Teks tidak akan memiliki makna bagi kehidupan masyarakat jika tidak dilakukan interpretasi atau penafsiran.

Posisi teks Al Qur an tidak dapat dipisahkan dari kondisi realitas sosialnya. Sebuah teks sangat dipengaruhi oleh historisitas dan subyektifitas yang mengitarinya, termasuk juga teks al-Qur'an. Sejakawal proses pewahyuan, alQur'an telah bersentuhan dengan bangsa Arab dan bahasa sosial budaya mereka. Setiap ayat yang turun tidak dipahami sebagai kalimat-kalimat yang tersendiri, melainkan berkaitan dengan kenyataan sehari-hari. Problem yang muncul lebih banyak disebabkan oleh benturan nilai-nilai yang dibawa al-Qur'an dengan nilainilai warisan leluhur yang berakar kuat dan menyatu dengan kehidupan mereka. Semangat dan misi al-Qur'an untuk menciptakan perubahan-perubahan yang lebih baik demi kemaslahatan manusia secara keseluruhan tidak selalu selarasdengan tradisi, budaya, pandangan hidup, keyakinan dan ikatan-ikatan primordial bangsa Arab waktu itu. ${ }^{3}$ Sehingga corak dan karakter suatu teks akan senantiasa menggambarkan dan merefleksikan struktur sosial budaya dan alam pikiran tempat teks tersebut dibentuk. Demikian juga dengan al-Qur an, kondisi sosiokultural masyarakat Arab atau kerangka sosial kebudayaan bangsa Arab saat itu banyak berpengaruh pada pembentukan teks al-Qur'an. ${ }^{4}$ Peristiwa pewahyuan sebagai titik awal lahirnya al-Qureean merupakan kata kunci untuk menyatakan bahwa ketika wahyu Ilahi tersebut diwahyukan kepada manusia dengan menggunakan bahasa kaum tertentu yaitu bahasa Arab, ${ }^{5}$ maka hal itu menandakan sifat kesejarahannya.

\section{Tafsir sebagai Penghubung Teks dengan Realitas Sosial}

Dialektika antara teks dengan realitas sosialnya dapat dilihat dari beberapa ayat al-Qur'an yang menjelaskan tentang upaya Rasulullah, pembawa risalah untuk membuat sebuah perubahan yang diistilahkan oleh al-Qur'an dengan min al-zhulumât ilâ al-nûr. ${ }^{6}$ Basis revolusi penafsiran al-Qur'an ini dapat

${ }^{2}$ Amîn al-Khûlî, Manâhij al-Tajdîd fì al-Nahw wa al-Balâghah wa al-Tafsîr wa al-Adâb, (Beirût: Dâr al-Ma,,rifah, 1961 M.), 78.

${ }^{3}$ Kondisi sosial ini dapat dilihat dari respon bangsa Arab yang periode awal resisten terhadap dakwah Rasulullah saw karena dalih mempertahankan tradisi leluhur mereka, hal ini dapatdijelaskan dalam beberapa ayat; QS. al-Baqarah [2:170], al-Mueminûn [23:24], al-A,râf [7:127], al-Furqân [25:43], al-Zukhruf [43:22].

${ }^{4} \mathrm{~J}$. Brugman, An introduction to History of Modern Arabic Literature in Egypt, (Leiden: Ej Brill, 1984 M), 338-340

${ }^{5}$ Lihat QS. Yûsuf [12:2], al-Syûrâ/26:195.

${ }^{6}$ LihatQ.S. al-Baqarah/2:257 
diklasifikasikan menjadi dua unsur yaitu kualitatif dan kuantitatif. Unsur kualitatif dimanisfestasikan dengan cara membentuk suatu kaidah bagi risalah Islam yang dapat dimanfaatkan, meskipun Rasulullah saw telah wafat. Hal ini dapat diperhatikan dalam ayat-ayat al-Qur'an secara umum yang menceritakan kejadian-kejadian ketika Rasulullah saw masih hidup, dalam beberapa tradisi dan adat istiadat serta perundang-undangan yang ada ketika itu. Secara garis besar ada tiga pembebasan yang telah dilakukan oleh Rasul saw ketika berdialektika dengan ummatnya. Pertama, pembebasan manusia dari kemusyrikan artinya, al-Qur'an berusaha membebaskan keyakinan masyarakat Jazirah Arab yang menganggap adanya perantara semu antara mereka dengan Allah. Mereka menganggap para perantara yang mereka imajinasikan memiliki kemampuan untuk mendatangkan manfaat dan bahaya yang telah bersenyawa dengan berhala-berhala yang terbuat dari batu. Mereka menyekutukan Allah Swt dengan patung-patung tersebut dalam ibadah dan doa mereka serta meyakini dengan menyembah berhala, merekapun akan semakin dekat dengan Allah Swt. ${ }^{7}$

Pembebasan kedua yang dilakukan Rasulullah di masyarakat Arab adalah pembebasan akal manusia dari mitos dan khurâfât. Masyarakat Arab mempercayai bahwa makhluk halus selalu mengelilingi mereka di tempat-tempat yang kosong. Makhluk tersebut akan menampakkan diri mereka kepada orangorang tertentu di antara mereka dalam bentuk yang beragam agar terbebas dari bencana yang mungkin akan menimpa mereka ketika dalam suatu perjalanan tertentu. Pembebasan ketiga yang telah dilakukan Rasulullah adalah membebaskan kehendak manusia dari belenggu hawa nafsu. Melalui tahapan pendidikan yang disebutkan dalam al-Qur'an kepada seorang Muslim, pada akhirnya seorang muslim sedikit demi sedikit mampu melawan segala bentuk hawa nafsunya dan segala bentuk keterpurukan diri mereka. Al-Qur'an mengajarkan agar menjadikan pengendalian diri sebagai sarana bagi seseorang untuk lebih berhati-hati ketika menghadapi apa yang dapat memancing hawa nafsunya. Tidak ada kekuatan yang dapat mencegah keinginan seseorang melainkan dengan cara pengendalian diri terhadap hal tersebut semaksimal mungkin. Rasulullah saw sendiri telah mengistilahkan proses pembebasan manusia dari belenggu hawa nafsunya dengan sebutan "jihâd akbar". ${ }^{8}$ Unsur kuantitatif dari revolusi al-Qur'an dapat dilihat pada arahan khusus bagi para penduduk Jazirah Arab untuk menciptakan suatu aturan bagi tersebarnya risalah Islam, sebagaimana disebutkan dalam QS. al-An'âm:[6:92].

\footnotetext{
${ }^{7}$ Abd al-Rahmân bin Muhammad Ibn Khaldûn, Muqaddimah IbnKhaldûn, (Beirût: Dâr alJail, t.th.), 160

${ }^{8}$ Bâqir al-Shadr, al-Islâm Yaqûd al-Hayâh, (Qum: Markaz al-Abhâts wa al-Dirâsât alTakhashshushiyyah li al-Syahîdal-Shadr, 1979 M), h. 35-36, lihat juga, Ghulen, Fathullah, Jihad Menegakkan Kalimat Allah, H. Ubaidillah (penerjemah), (Istambul: al-Zaman, 1996 M), 56
} 


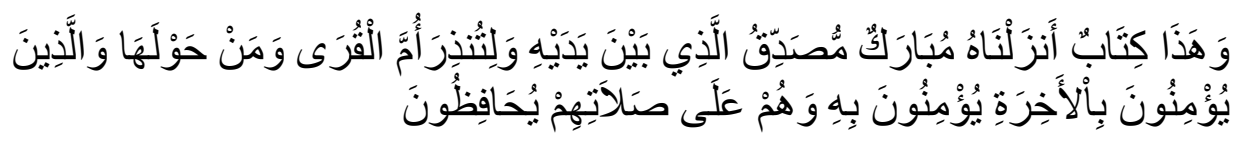

Terjemahannya: "Dan ini (al-Qur'an) adalah kitab yang telah Kami turunkan yang diberkahi; membenarkan kitab-kitab yang (diturunkan) sebelumnya dan agar kamu memberi peringatn kepada (penduduk) Ummul Qura (Mekah) dan orang-orang yang di luar lingkungannya. Orang-orang yang beriman kepada adanya kehidupan akhirat tentu beriman kepadanya (alQur'an) dan mereka selalu memelihara shalatnya”. (QS. 6:92)

Jazirah Arab dalam ayat tersebut tidak menunjukkan bahwa masyarakat Jazirah Arab memiliki keistimewaan tertentu daripada umat manusia yang lainnya, tetapi hal itu lebih dikarenakan untuk mewujudkan tujuan yang bersifat kuantitas bagi tegaknya risalah Islam, mereka dipandang sebagai lahan misi Rasulullah juga menunjukkan tempat risalah Islam dimulai, yakni Jazirah Arab tersebut. ${ }^{9}$ Proses perjalanan dakwah Rasulullah tersebut menunjukkan bahwa nilai-nilai normatif al-Qur'an memiliki dimensi transformatif. Wahyu Ilahi alQur'an bukan hanya berisi dogmatis atau ajaran yang hanya memfokuskan pada hubungan manusia dengan Tuhannya tetapi juga mempedulikan juga hubungan kemanusiaan. ${ }^{10}$ Penjelasan tersebut sekaligus mengisyaratkan bahwa sejak awal al-Qur'an diwahyukan telah terjadi interpretasi teks atau penafsiran al-Qur'an. Dengan kata lain pada masa awal pewahyuan telah terjadi dialektika antara alQur'an sebagai teks dan kondisi sosio-kultural masyarakat Arab sebagai realitas.

Proses dialektika antara teks al-Qur'an dengan realitas sosialnya mengalami perubahan pasca Rasulullah wafat. Setelah proses pewahyuan paripurna dan tidak ada lagi Rasul saw sebagai figur yang dipercaya paling memahami kandungan makna al-Qur'an, maka teks al-Qur'an tidak lagi berdialog langsung menghampiri audiensnya melalui sosok Rasulullah, tidak lagi datang secara berangsur-angsur dan tidak lagi menyesuaikan diri dengan bahasa audiensnya. Dampak dari perubahan ini antara lain hubungan dialog yang telah dibangun oleh al-Qur'an pada masa turunnya berubah menjadi monologis. Artinya, al-Qur'an sudah tidak lagi aktif berdialog tetapi sebaliknya menunggu untuk diajak berdialog atau cenderung dipahami secara doktrinal. Pelbagai diskursus, peristiwa dan konteks yang melingkupi turunnya al-Qur'an tidak akan terulang sama persis pada saat ini. Kondisi sosial kemasyarakatan Nabi Muhammad Saw, ketika menerima wahyu sekaligus cara beliau menafsirkannya dan mengaplikasikannya dalam sebuah prilaku juga tidak akan dapat dirasakan oleh umat Islam sekarang dan masa yang akan datang.

\footnotetext{
${ }^{9}$ Hasan IbrâhîmHasan, Târîkh al-Islâmî: al-Siyâsî, al-Dîn̂̂, al-Tsaqafî, al-Ijtimâ '̂, (Kairo: Makatabah al-Nahdhah al-Mishriyyah, 2001 M.)

${ }^{10}$ Bâqir al-Shadr, al-Islâm Yaqûd al-Hayâh, h. 24; Lihat juga, Kuntowijoyo, Paradigma Islam, (Bandung:Mizan, 1991 M.), 170.
} 
Realitas sosial ini menunjukkan bahwa ada rentang waktu yang sangat panjang antara al-Qur'an sekaligus nabi Muhammad dengan umat Islam yang hidup dalam dunia modern sekarang. Karenanya tantangan yang harus dihadapi para mufassir tentang perkembangan kajian teoritis tafsir sosial, sehingga mereka dapat menjelaskan dan mengungkapkan maksud daln kandungan makna al-Qur'an yang telah diwahyukan pada masa lalu tetapi harus tetap bisa dijadikan pedoman hidup sampai akhir masa. Realitas yang melingkupi turunnya al-Qur'an otomatis tidak akan sama dengan realitas generasi-generasi sesudahnya termasuk realitas masa kini. ${ }^{11}$ Perubahan kondisi realitas sosial masyarakat inilah yang meniscayakan adanya ketidakstagnanan dalam penafsiran al-Qurean. Penafsiran ayat-ayat al-Qurean meniscayakan adanya pengembangan dan perubahan sesuai dengan kondisi sosial masyarakatnya.

\section{Tafsir Menjawab Problem Realitas Sosial}

Sebuah tafsir haruslah sesuai dengan zamannya agar tidak terkesan usang dan dapat diaplikasikan oleh masyarakat zamannya. Upaya menyesuaikan bahasa penafsiran atau problem utama penafsiran dengan realitas sosial merupakan upaya mengkontekstualisasikan ayat. Menafsirkan ayat dengan konteks kekinian dengan tetap memperhatikan konteks awal ayat (asbab al-nuzul) akan dapat mempertahankan nilai universalitas al-Qurean. Artinya, terkungkung dengan tradisi atau penafsiran klasik tanpa pembacaan kritis baik dari sisi materi ataupun metodologinya justru akan mengurangi universalitas al-Quran. Langkah ini untuk menghindari penafsiran atau pemahaman turun temurun yang belum tentu semuanya benar dan tidak seluruhnya dapat menjawab tantangan zaman. ${ }^{12}$

Kehidupan sosial kemasyarakatan merupakan jaringan sosial yang mengikat orang menjadi suatu kehidupan bersama. Jaringan sosial ini bersifat dinamis atau selalu berubah. Semua realitas sosial senantiasa berubah dengan derajat, kecepatan dan tempo yang berbeda-beda. Realitas sosial tidak dapat dipahami sebagai realita yang statis, tetapi merupakan sebuah sistem atau suatu entitas yang tidak dapat dipahami hanya dari dinamika hubungan organik bagianbagiannya dalam dimensi ruangnya saja, tetapi juga harus dipahami dinamikanya dalam dimensi waktu yaitu pertumbuhan, perkembangannya dan perubahannya dalam perjalanan sejarah. Keniscayaan adanya perubahan dalam masyarakat meniscayakan pula adanya perubahan dalam sebuah penafsiran. "Perubahan" di sini bukan berarti perubahan yang meninggalkan akarnya, perubahan tanpa pijakan dan tanpa rambu, melainkan sebuah perubahan pendekatan penafsiran yang tetap berpegang teguh pada kaidah-kaidah tafsir atau ushul al-tafsir. Hasil

\footnotetext{
${ }^{11}$ Nashr Hâmid Abû Zaid, Mafhûm al-nashshDirâsah fì 'Ulûmal-Qur'ân, 10-11.

${ }^{12}$ Nurcholish Madjid, "Pendahuluan" dalam Budhy Munawar Rahman (editor),Kontekstualisasi Doktrin Islam dalam Sejarah, (Jakarta: Paramadina, 1995 M.), xxiii
} 
pembacaan, pengamatan dan budaya masyarakat mufassir hendaknya juga dijadikan tolok ukur proses penafsiran.

Banyaknya turats tafsir dengan ragam bentuk dan corak yang telah diwariskan oleh mufassir-mufassir masa lalu merupakan contoh konkrit dari adanya keterkaitan realitas mufassir dengan teks tafsir yang telah dihasilkan. Oleh karena itu, satu hal yang tidak bisa ditinggalkan dalam pembacaan teks tafsir adalah memahami background atau biografi selengkapnya dari penulis tafsir. Pemahaman terhadap figur setiap mufassir akan memudahkan pembaca menemukan argumentasi masing-masing mufassir melahirkan teks tafsir dengan beragam kecenderungan. Misalnya tafsir "al-Kasysyaf" merupakan hasil komunikasi dari seorang muetazili yang ahli lughah dengan sebagian masyarakatnya. Dalam muqaddimahnya disebutkan: "... Mereka menginginkan adanya kitab tafsir dan mereka meminta saya supaya mengungkapkan hakikat makna al-Qur'an dan semua kisah yang terdapat di dalamnya termasuk segi-segi penakwilannya..."13 Demikian juga dengan penjelasan yang filosofis Fakhruddin al-Razi dalam tafsir al-Kabirnya sangat terkait dengan kondisi masyarakatnya. AlRazi hidup pada masa pertengahan abad VI H. Dalam masa itu ia mengalami adanya pertentangan madzhab akidah antara golongan Sunni, Syiah, Mu'tazilah dan membantah beberapa argumen akidah Mu'tazilah, dalam hal ini tafsir alKasysyaf adalah sasarannya. Begitu seterusnya dengan semua karya tafsir yang ada pasti terkait dengan subyektifitas dan kondisi masyarakat saat itu. Inilah bukti bahwa teks-teks tafsir yang telah dikonsumsi oleh ribuan pengkaji tafsir adalah hasil respon setiap mufassir terhadap realitasnya masing-masing.

Penjelasan di atas sekaligus menunjukkan bahwa dari sisi informasi keilmuan, produk-produk tafsir masa lalu sangat kaya informasi, bahkan bisa dikatakan tanpa kehadiran tes-teks tafsir tersebut kaum muslimin akan menemui kesulitan dalam memahami masing-masing ayat lengkap dengan ragam qira'at, gramatikal, sabab al-nuzul, munasabah dan lain-lain. Namun, dari sisi pengamalan dari paparan teks tafsir tersebut perlu adanya pertimbanganpertimbangan. Karena sangat dimungkinkan ada beberapa penjelasan dalam tafsir tersebut yang tidak layak diterapkan dalam konteks kekinian. Inilah tugas mufassir dan penafsir saat ini.

\section{Tafsir Al-Qur'an dalam Konteks Indonesia}

Indonesia memiliki para ulama mufassir al Qur an dengan latar belakang yang beragam, diantaranya ada dua mufassir dengan latar belakang berbeda dalam aktivitas sosial yang penulis ketengahkan dalam makalah perkembangan kajian teoritis tafsir sosial ini, yakni Syu'bah Asa seorang wartawan santri yang mengulas kritik sosial politik Indonesia dengan pendekatan ayat-ayat Al-Qur'an

${ }^{13} \mathrm{Al}$-Zamakhsyari, al-Kasysyaf 'an Haqa'iq al-Tanzil wa'Uyun al Aqawil Wujuh alTa'wil, (t.tp: Intisyarat Aftab, t.th.)m jilid 1, 17-20 
dan Dr. Quraish Shihab ulama Tafsir Indonesia yang terkenal dengan karya Tafsir Al Misbah. Kemunculan tafsir yang kental dengan nuansa yang berbeda-beda seperti nuansa bahasa, fiqh, tasawuf, sosial-politik, dan lainnya itu tidak bisa dilepaskan dari perkembangan problem sosial keagamaan masyarakat. Hal ini disebabkan problem sosial keagamaan semakin kompleks dan perkembangan ilmu pengetahuan yang semakin pesat. Masing-masing tafsir tersebut mencoba untuk memberikan solusi dari problem yang dihadapi masyarakat.

Selain problem masyarakat yang semakin kompleks, perbedaan pola pikir dan cara pandang mufassir dalam memandang ayat al-Qur'an juga menjadi pemicu perbedaan penafsiran. Dari perbedaan penafsiran tersebut maka secara otomatis melahirkan produk penafsiran dengan berbagai corak perbedaan epistemologi dan cara pandang mufassir terhadap suatu ayat dipengaruhi oleh beberapa faktor. Diantaranya adalah adanya perbedaan situasi sosio-historis di mana seorang mufassir hidup. Selain itu, faktor pendidikan mufassir juga turut serta memberi warna dalam corak penafsirannya. Bahkan situasi politik yang terjadi ketika mufassir melakukan kerja penafsiran juga sangat kental mewarnai produk tafsirnya. Perubahan untuk menggeser paradigma merupakan hal yang penting karena perkembangan tafsir banyak dipengaruhi oleh perubahan dan perkembangan epistemologi. Hal tersebut dirasa penting karena meskipun situasi dan kondisi telah berubah tetapi bila epistemologi tafsirnya tidak berubah maka perkembangan tafsir di Indonesia khususnya, akan berjalan di tempat dan terjadi stagnasi. Akibatnya, tafsir terjebak pada pengulangan pendapat-pendapat masa lalu yang belum tentu relevan pada konteks keindonesiaan. ${ }^{14}$

Penafsiran al-Qur'an di Indonesia sudah berjalan lama. Hal ini dimulai sejak abad 17 yang ditandai dengan munculnya Tarjuman al- Mustafid karya 'Abd ar-Rauf Singkel dalam tulisan ArabMelayu hingga abad 20. Dalam masa kurang lebih empat abad itu telah banyak tafsir al-Qur'an yang dihasilkan umat Islam Indonesia dengan berbagai macam corak. ${ }^{15}$ Pada periode 1990 -an di Indonesia muncul beragam karya tafsir dari intelektual muslim Indonesia. Dinamika sosial dan politik di Indonesia sangat mempengaruhi pemikiran para cendekiawan muslim khususnya para mufassir Indonesia. Hal ini berimbas pada produk tafsir mereka sehingga tiap tafsir memiliki corak dan latar belakang yang berbeda.

\section{Kontribusi Media Massa dalam Teori Tafsir Sosial}

Indonesia pernah mengalami pemerintahan pada masa orde baru. Dalam sejarah, rezim orde baru, Negara meneguhkan kekuasaannya dalam bentuk vii

${ }^{14}$ Abdul Mustaqim, Pergeseran Epistemologi Tafsir, Pustaka Pelajar, Yogyakarta, 2008,

${ }^{15}$ M. Yunan Yusuf, “Karakteristik Tafsir al-Qur'an di Indonesia Abad Keduapuluh", Ulumul Qur'an, Vol.III, No.4, 1992, 50 
kepatuhan dan kedisiplinan pada penguasa dalam rangka menjamin stabilitas politik agar pembangunan yang telah direncanakan agar berjalan dengan baik. Di sepanjang kekuasaan orde baru, Negara berhasil mengontrol masyarakat bukan sekedar untuk disiplin dan patuh atas nama warga negara yang baik tetapi lebih jauh lagi ia mampu mengendalikan pemikiran dan gagasan di bawah bayangbayang kepatuhan pada ideologi penguasa dalam kehidupan sosial politik masyarakat.

Kepatuhan ini terlihat pada kebebasan media massa. Media massa yang seharusnya berfungsi sebagai kontrol sistem pemerintahan, justru berada di bawah bayang-bayang intimidasi pemerintahan orde baru. Sebelum lengsernya Presiden Soeharto, pemerintahan orde baru dilanda krisis di berbagai dimensi termasuk krisis moral. Adanya berbagai peristiwa tersebut maka muncullah sejumlah karya tafsir yang mengambil sikap kritis terhadap rezim orde baru. Salah satunya adalah tafsir karya Syu'bah Asa yang berjudul Dalam Cahaya al-Qur'an : Tafsir AyatAyat Sosial Politik. Karya ini merupakan representasi dari tafsir yang secara lugas melakukan kritik atas rezim orde baru. Arah visi, gerakan dan wacana yang dikembangkan tafsir ini telah memberikan muatan kritis dan perlawanan terhadap zaman orde baru.

Buku tafsir ini berjudul “Dalam Cahaya al-Qur'an TafsirAyat-ayat Sosial Politik”, diterbitkan oleh PT. Gramedia PustakaUtama Jakarta tahun 2000. Jumlah halaman 482. Isi dari buku ini merupakan tulisan-tulisan Syu'bah Asa dalam majalah Panji Masyarakat. Ada 57 tema yang diuraikan dan dikelompokkan menjadi tujuh bagian. Pertama, "Kepada Bangsa -bangsa", terdiri : kepada bangsa- bangsa; kepada agama-agama; siapa saja yang selamat (Yahudi, juga Nasrani; yang benci dan yang dicinta; biara, gereja, dan sinagog, dan masjid; dibunuh, diculik, dianiaya. Kedua, "Amanat untuk Semua", terdiri : amanat untuksemua; kepada langit, bumi dan gunung-gunung; dari benteng bani Quraidzah; puasa, amanat, dan buruh; siapakah penguasa; musyawarah walaupun gagal; musyawarah, dari pangkalnya; musyawarah, monopoli, dan senjata; tentang Islam yang total; perang untuk kemerdekaan; kepada pahlawan

Kondisi sosial politik menjadi dayat magnet dalam penafsiran ini, sehingga pokok soal kecamuk antar umat dibahas dalam poin ketiga, "Guncangan demi Guncangan”, terdiri: guncangan demi guncangan; berjalan diantara guncangan; pemerintah yang rasialis; karunia yang hilang; di sekitar tafsir Bung Karno; keganasan dan partai-partai; PKI dan superioritas Allah; kerusuhan dan desas desus; bencana yang menjalar; orang yang merasa berbuat baik. Keempat, "Tali Allah dan Tali Manusia", terdiri : tali Allah dantali manusia, takwa yang bagaimana; memecahkan perpecahan; persaudaraan yang bisa kisruh; misi yang mulia dan sederhana; dakwah, juga untuk pendosa; siapakah umat terbaik; umat terbaik dan tafsiran baru; tentang umat yang tengah-tengah 
Setiap masalah tentu ada solusi dan setiap bangsa mempunyai sejarahnya sendiri, Al Qur'an hadir sebagai pedoman bagi umat dalam menata kehidupan sosial kemasyarakat dan juga sosial politik, dalam konteks ini, bahasan pokok kelima, "Dari Kotoran Sejarah", terdiri: bila Muslim melawan Muslim; bagaimana memecah agama; persaudaran dan pengkhianatan; para sekularis pertama. Keenam, "Keadilan dan Kesaksian Allah", terdiri : keadilan dan kesaksian Allah; apa yang disebut Adil; keadilan atau kehancuran; keadilan dan kebencian; keadilan dan mantan presiden; berita dari orang fasik. Ketujuh, "Memasuki Konteks Baru”, terdiri : tobat, juga untuk pejabat; pers yang fasik dan yang berpahala; harta haram dan mafioso; para penguasa dan para pemilih; bagaimana minoritas mengalahkan mayoritas; perempuan dan keindahan; selamat datang, presiden baru; dikorbankan untuk menjadi presiden; dan mem memasuki konteks budaya baru. Memberikan subtansi teori tafsir sosial hadir dalam kontesk kekinian yang ada benang merah dengan sejarah bangsa menuju kemajuan, sehingga problem sosial yang ada di urai dengan kalimat-kalimat penafsiran yang ada dalam pesan subtansi ayat-ayat Al Qur'an.

Profil gaya penulisan tafsir ini merupakan representatif dari penulisnya yang merupakan wartawan dan mempunyai skill keilmuan keagamaan dengan latar belakang santri, racikan yang apik dengan menggunakan gaya bahasa kolom yaitu gaya penulisan tafsir dengan menggunakan kalimat yang pendek dan tegas. Dalam bentuk ini, biasanya diksi-diksi yang dipakai dipilih melalui proses serius dan akurat. Diksi yang dipilih itu, menyimpan kekuatan yang mampu menghentakkan imajinasi dan batin pembaca. Gaya bahasa kolom dengan pilihan diksi yang tepat seperti ditunjukkan Dalam Cahaya al-Qur'an ini, tidak hanya mengajarkan kita tentang mekanisme komunikasi efektif dalam sebuah tulisan tetapi juga memberikan kekuatan khas yang bisa dirasakan pembaca. Gaya bahasa penulisan tafsir ini dapat ditemukan pada Dalam Cahayaal-Qur'an. Simak contoh berikut:

... Umat Muslimin, yang shalat menghadap ka'bah, demikian dikatakan, bisa dibayangkan membentuk garis-garis lingkar di bumi, yang semakin jauh dari poros semakin melebar. Itu bisa menunjukkan "kebenaran" ini : makin jauh dari pusat (ka'bah) orang makin renggang. Makin dekat, mereka makin rapat, menyatu, dan mampu menghapuskan faktor perbedaan atau semacam itu. Ini menarik, tetapi tidak relevan. Pertama, apa hubungan garis yang makin rapat, yang adalah satu hal, dengan persamaan dan perbedaan yang adalah hal lain. Kedua, kalau pun gambaran ini mau dipakai, mengapa garis lingkar harus makin melebar ketika menjauh dari pusat? Bisa saja kita bikin bulatan dengan jarak yang sama persis antargaris. Misalnya, seperti obat nyamuk. Yang benar ialah ini : persatuan tidak ada hubungannya dengan kesamaan. Persatuan juga 
tidak selalu menunjuk pada kesatuan. Dan saling pengertian tidak ada hubungannya dengan keseragaman. ${ }^{16}$

Pada alenia terakhir dari kutipan di atas memperlihatkan ketegasan Syu'bah dengan bahasa yang khas: "Yang benar ialahini: persatuan tidak ada hubungannya dengan kesamaan. Persatuan juga tidak selalu menunjuk pada kesatuan. Dan saling pengertian tidak ada hubungannya dengan keseragaman”. Gaya bahasa penulisankolom yang di iringin penafsiran sumber rujukan ini, telah melahirkan pendekatan teori tafsir sosial, mudah dipahami atas realitas sosial yang sedang berlangsung, terjawab dengan pemaknaan konsepsional dan memberikan panduan bagi pembaca dalam memahami makna tersirat dari perdebatan realitas sosial tersebut. Lebih lanjut, rubrik tajuk masalah sosial politik di majalah Panji Masyarakat yang sengaja disediakan bagi Syu'bah untuk menulis artikel majalah mingguan yang terbit setiap minggu, berlangsung dalam rentang waktu 1997 hingga 1999. Pada saat itu, dinamika sosial politik mengalami kegentingan yang luarbiasa, proses menuju runtuhnya tatanan sosial politik orde baru menuju era baru reformasi politik berlangsung begitu mengkuatirkan sebagai bangsa yang majemuk. Media massa sebagai informasi utama perkembangan sosial politik, merupakan telaah tafsir sosial dalam setiap artikel yang ditulis sesuai dengan isu yang berkembang, karena itu sebagai kumpulan artikel yang terpenggal dan demi publikasi media massa, tema-tema yang diambil Syu'bah Asa sangat beragam dan kontekstual yakni sesuai dengan peristiwa-peristiwa yang muncul pada saat tafsir itu ditulis. Sehingga judul "Dalam Cahaya al-Qur'an; Tafsir ayat-ayat Sosial Politik" yang dipakai dalam buku ini sendiri sebetulnya adalah nama yang berupaya merajut setiap tema dalam rublik ini atas kondisi sosial politik dengan pendekatan penafsiran yang lekat sebagai tafsir sosial .

Pada tafsir ini, setiap ayat yang dikemukakan selalu disesuaikan dengan waktu kejadian dan tempat itu. Setting sosial politik dalam tafsir sosial ini bermula dari tulisan yang dimuat di majalah Panji Masyarakat. Sehingga ayatayat al Qur'an yang ditafsirkan merupakan respon terhadap peristiwa-peristiwa sosial politik yang sedang berlangsung dalam ruang sosial Syu'bah Asa yakni Indonesia. Kutipan ayat-ayat Al Qur'an adalah cahaya yang menyoroti kejadiankejadian sosial politik yang lagi trend pada masa itu. Karena itu, penyematan sebagai salah satu tafsir sosial merupakan kebutuhan tafsir yang sesuai dengan konteks zaman pada periode akhir orde baru hingga awal reformasi. Sumbangsih Syu'bah Asa dalam memberikan penafsiran terhadap perkembangan sosial politik dengan menggunakan rujukan ayat-ayat al Qur' an dan khazanah pemikiran intelektual Islam, baik klasik maupun modern, telah menempatkan sebagai salah

${ }^{16}$ Syu'bah Asa, Dalam Cahaya al-Quran,: Ayat-ayat Sosial Politik (PT Gramedia),13-14 
satu icon intelektual muslim yang mampu membaca zaman dari sudut pandang alQur'an. ${ }^{17}$

Tafsir Syu'bah Asa merupakan tafsir yang kental dengan nuansa sosial politik Indonesia era akhir orde baru dan awal reformasi. Faktor sosial politik yang berkembang saat itu cukup mempengaruhi gaya mufassir, hal ini muncul sebagai respon untuk mencoba menyikapi peristiwa-peristiwa yang terjadi pada zaman orde baru yang tidak sesuai dengan petunjuk al-Qur'an. Syu'bah Asa dikenal sebagai wartawan senior sekaligus seorang budayawan dengan latar belakang santri. Pergumulan intelektual yang mempengaruhi karakteristik Syu'bah Asa menjadi seorang mufassir yang berani melontarkan kritik yang lugas terhadap pemerintah, merupakan jawaban atas pendekatan tafsir sosial sebagai alternatif penafsiran. Sejak semula penulisan tafsir sosial ini memang dirancang dengan pendekatan kontekstual sehingga ruang sejarah tempat ia berada menjadi medan gerak tafsirnya. Syu'bah selalu mengarahkan eksplorasi tafsir pada konteks sejarah Indonesia dibawah kendali rezim Soeharto.

Meskipun tafsir ini menggunakan pendekatan konteks namun tafsir ini terkadang masih terlihat tekstualitas dalam hal makna. Tekstualitas makna ini digunakan sebagai tambahan wacana dan hanya digunakan untuk pembahasan dalam analisis kebahasaan saja. Kontekstualitas tetap lebih dominan dalam karya Syu'bah ini, dengan pendekatan tafsir yang menjadikanal- Qur'an sebagai kritik sosial. Ini membuktikan bahwa al-Qur'an hidup dan berbicara sehingga dapat menjadi petunjuk setiapsejarah kemanusian. Sebagai salah satu dari sekian representasi pemikir intelektual muslim Indonesia yang menelaah realitas sosial saat itu dengan pendekatan tafsir dan disalurkan oleh media, telah menjadi jalan yang memperlancar kebutuhan pendekatan teori tafsir sosial harus menajdi bagian tidak terpisahkan dalam kohesi sosial politik pada setiap zamanya.

Gaya penafsiran dengan cara yang dilakukan Syu'bah Asa yang diperlihatkan dalam tafsir sosial ini adalah epistemologi yang bersandar pada akal, yakni memberi penilaian dan keputusan terhadap informasi-informasi yang masuk lewat indra. Sumber epistemologi ini adalah realitas dan empiris. Realitas dalam hal ini dapat berupa realitas alam, sosial kemanusiaan, maupun keagamaan. ${ }^{18}$ Pada tafsir ini, Syu'bah melihat realitas sosial kemanusiaan yang ada di sekitarnya sebagai medan keberangkatan tafsirnya. Metode yang digunakan dalam tafsir ini adalah metode tematik. Hal ini dapat dilihat pada penafsirannya yang terdiri dari tema-tema yang aktual dan faktual sesuai peristiwa yang terjadi saat itu. Pada saat mengurai produk tafsir biasanya Syu'bah Asa mengkomparasikan pendapat

\footnotetext{
${ }^{17}$ Kuntowijoyo, "Kata Pengantar" dalam Syu'bah Asa, Dalam Cahaya al- Qur'an: Tafsir Ayatayat Sosial-Politik, (Jakarta: Gramedia, 2000), X

${ }^{18}$ Fathul Mufid, Filsafat Ilmu Islam (Kudus: STAIN KUDUS, 2008), 124
} 
beberapa mufassir kemudian ia mentarjihnya atau hanya sekedar menampilkan saja. Hal ini menarik, menjadi rujukan dalam pendekatan tafsir sosial.

Teori kebenaran dalam tafsir ini bertumpu pada hakikat al-Qur'an yakni penyelamatan dan pembebasan kemanusiaan (emansipatoris) seperti yang dilakukan Nabi Muhammad swa dengan bimbingan Allah swt. Corak tafsir emansipatoris mengasumsikan penalaran metodis yang bersifat kontekstual. Interpretasi pada al-Qur'an harus melibatkan pemahaman atas situasi sosial historis empiris baik situasi pada saat al-Qur'an diturunkan dan situasi saat alQur'an hendak diterapkan (konteks). ${ }^{19}$ Mufassir mengikuti prinsip kontekstualisasi bahwa penafsiran al-Qur'an harus kontekstual dan mampu menjadi solusi bagi masyarakat Indonesia. Dalam metode ini, seorang mufassir ketika berhadapan dengan teks harus bergerak dari situasi sekarang ke masa lampau guna melihat konteks sosio-historisnya untuk menemukan esensi ayat.

Upaya kontekstualisasi pemaknaan ayat al-Qur'ean adalah dengan cara menyesuaikan bahasa penafsiran atau problem utama penafsiran dengan realitas sosial yang ada. Langkah ini untuk menghindari pemahaman turun temurun yang belum tentu semuanya benar dan tidak seluruhnya dapat selaras realitas kekinian. ${ }^{20}$ Produk tafsir yang mempertimbangan kondisi dan problem masyarakat setempat akan lebih realistis bukan sekedar normatif, akan lebih "membumi" dan tidak terkesan "melangit" dan pada akhirnya akan mudah dipahami dan diaplikasikan dalam kehidupan keseharian. Inilah keunggulan dari teori tafsir sosial, bahwa kehadiran tafsir menjawab realitas yang sedang berlangsung dan memberikan gudline bagi masa depan. Meskipun pada satu sisi, kondisi sosial kemasyarakatan yang beda suku dan budaya sangat berpengaruh pada cara mereka menafsirkan ayat-ayat al-Qur'an termasuk mengaplikasikannya dalam bentuk ritual-ritual keaagaman, karena itu, tidaklah heran jika muncul penamaan Agama yang di ikuti oleh tempat dimana Agama tersebut berada, misalnya muncul istilah "Islam Mesir", "Islam Iran", "Islam Amerika", "Islam Indonesia" dan lain-lain. Penamaan istilah-istilah tersebut menunjukkan bahwa di dalam Islam terdapat ajaran-ajaran yang bersifat universal tetapi dalam penafsiran tetap memperhatikan lokalitas dan cara memahami ajaran universal tersebut berbeda-beda.

Seorang mufassir Indonesia tidak akan sama penafsiran, pemahaman dan cara penerapannya dengan mufassir Amerika, karena secara logika problem realitasnya pasti berbeda. Konteks yang mengitari lahirnya teks tafsir di Amerika tidak akan sama persis dengan konteks yang mengiringi lahirnya teks tafsir di Indonesia. Keadaan seperti ini diistilahkan oleh Prof. Dr. Quraish Shihab dengan logika prioritas. Ketika kontak dengan teks al-Qur'an sekaligus kitab-kitab

\footnotetext{
${ }^{19}$ Hendar Riyadi, TafsirEmansipatoris (Bandung, Pustaka Setia2005), 66.

${ }^{20}$ Nurcholish Madjid, "Pendahuluan" dalam Budhy Munawar Rahman (editor), Kontekstualisasi Doktrin Islam dalam Sejarah, (Jakarta: Paramadina, 1995 M.), xxiii
} 
tafsirnya, mufassir harus menyadari bahwa masing-masing ayat tersebut memiliki latar belakang tersendiri sehingga diterjemahkan oleh para mufassir dengan beragam penafsiran, hal ini tidak bertentangan dengan datangnya Islam sebagai Agama rahmatal lil alamin.

\section{Kebutuhan Terkait Pendekatan Tafsir Sosial}

Urgensi tafsir sosial berangkat dari kenyataan bahwa teks al-Qur'an telah final dan terus berkaitan dengan konteks situasi sosial diturunkannya, karena itu, untuk menjawab perkembangan sosial kemasyarakatan yang terus bertransformasi memerlukan seperangkat alat dan teori akademik, dalam mendeteksi dinamika wacana yang terus berkembang. Dialektika merupakan cerminan alat deteksi dini dalam memberikan pemaknaan konsepsional pendekatan tafsir sosial, sebagaimana teori dialektika ada 3 (tiga) hal yang saling terkait dengan konteks sosial, ${ }^{21}$ : (1) Kontestasi wacana, yakni halhal yang sedang terjadi dan yang sedang berlangsung. (2) Pelibatan wacana, yakni orang-orang yang terlibat, sifat, kedudukan, serta peran, (3) Sarana dan prasarana wacana, yakni bagian yang sedang diperankan oleh bahasa dalam situasi dan kondisi sosialnya.

Melalui logika semiotika sosial ini, kurang layak jika mufassir masa kini masih berpegang teguh sepenuhnya dengan model penafsiran ratusan tahun yang lalu. Teks dan akan terlepas dari konteks sitausinya, karena itu, dialektika alQur'an tidak dapat terpisah dengan dua sisi tersebut. Kebutuhan baru dan semangat "tafsir al-Qur'an menjadi rujukan sosial kemasyarakatan" mufassir tidak mungkin hanya mentransfer ulang pemikiran mufassir-mufassir sebelumnya, karena "kondisi realitas dan kegelisahan" masyarakat Indonesia pasti berbeda dengan realitas masyarakat luar sana. Inilah pekerjaan utama para mufassir Indonesia yang sering bersentuhan dengan penafsiran ayat-ayat al-Qur'an. Kebutuhan pendekatan tafsir sosial merupakan keniscayaan dalam menghadirkan ajaran agama Islam yang rahmatal lil alamin.

Dialektika al-Qur'an dengan realitas sosial dimana masyarakat arab (mekkah dan madinah) menjadi tempat diturunkan wahyu, yang kita kenal dengan ilmu asbabun nuzul, memberikan penjelasan, bahwa realitas sosial merupakan bagian tidak terpisahkan ketika menarasikan tafsir al Qur'an. Penyampaian risalah kenabian juga sangat lekat dengan dinamika dan realitas sosial pada saat itu, jadi, pendekatan teoritis tafsir sosial, merupakan implementasi dari dialektika sosial kemasyarakatan yang digali oleh para mufassir untuk kemaslahatan umat. Untuk menjembatani nuansa diakletika dalam penafsiran al Qur'an, Amin al-Khuli ${ }^{22}$ menulis kitab dirāsah mā fi al-Qur'ān dan dirāsah māḥawla al-Qur'ān tersebut,

${ }^{21}$ Halliday dan Ruqayya Hasan, Bahasa, Konteks, dan Teks: Aspek-aspek Bahasa dalam Pandangan Semiotika Sosial, (Yogyakarta: Gadjahmada University Press, 1994), 16.

${ }^{22}$ Amin Al-Khulli dan Nasr Hamid Abu Zaid Metode Tafsir Sastra, ter. Khairon Nahdiyyin, (Yogyakarta: Adab Press, 2004), 64. 
kajian dialektika tafsir al Qur'an akan menampilkan gambaran realitas sosial yanng hidup para mufassirnya dengan kondisi sosial sosial politik sebagai konsteasi kehidupan kemasyarakatan dengan cerminan rujukan al Qur'an. Adanya ruang kehidupan yang terus berlangsung dan teks ayat al Qur'an telah sempurna, menurut Syahrur, dialektika tafsir al Qur'an merupakan space yang perlu diperhatikan dengan realitas masayarakat terus mengalami transformasi (an-naș mutanāhiyah wa al-wāqi ' gairu mutanāhiyah). ${ }^{23}$

\section{Penutup}

Menurut Quraish Shihab penafsiran Rasûlullah dapat dikategorikan menjadi dua yaitu pertama, penafsiran terhadap masalah yang bukan dalam wilayah nalar, misalnya tentang ajaran tauhîd, ibadah dan lain-lain. Kedua, masalah-masalah yang masuk dalam wilayah nalar, misalnya masalah sosial kemasyarakatan. Kategori kedua inilah yang harus didudukkan pada proporsinya yang tepat sehingga meniscayakan adanya perubahan dalam penafsiran teks alQurean. Berdasarkan penjelasan yang telah diutarakan mengarah pada adanya keharusan menghasilkan produk tafsir yang kontekstual-realistis-aplikatif. Maksud al-Qur'an diwahyukan dalam masyarakat atau konteks tertentu, maka upaya penafsirannya saat ini juga harus memperhatikan konteks atau kondisi saat ini. Istilah kontekstualisasi al-Qur'an, yakni Penggunaan nalar zaman dalam proses membangun penafsiran, disertai sistem pengetahuan dan aspek kehidupan manusia pada abad ke 21, baik sosial, budaya, politik telah jauh berkembang dan pasti berbeda dengan abad-abad sebelumnya. Upaya kontekstualisasi pemaknaan ayat al-Qure an adalah dengan cara menyesuaikan bahasa penafsiran atau problem utama penafsiran dengan realitas sosial yang ada. Langkah ini untuk menghindari pemahaman turun temurun yang belum tentu semuanya benar dan tidak seluruhnya dapat selaras realitas kekinian. Produk tafsir yang mempertimbangan kondisi dan problem masyarakat setempat akan lebih realistis bukan sekedar normatif, akan lebih "membumi" dan tidak terkesan "melangit" dan pada akhirnya akan mudah dipahami dan diaplikasikan dalam kehidupan keseharian. Inilah keunggulan dari teori tafsir sosial, bahwa kehadiran tafsir menjawab realitas yang sedang berlangsung dan memberikan gudline bagi masa depan.

\section{Daftar Pustaka}

Abd al-Rahmân bin Muhammad Ibn Khaldûn, Muqaddimah Ibn Khaldûn. Beirût: Dâr al-Jail, t.th.

Abdul Mustaqim, Pergeseran Epistemologi Tafsir, Pustaka Pelajar, Yogyakarta, 2008.

Abd al-Azhîm al-Zarqânî, Manâhil al- 'Irfân. Beirût: Dâr al-Jail, t.th.

${ }^{23}$ Muhammad Syahrur, al-Kitāb wa al-Qur'ān: Qirā'ah al-Mu'āṣirah (Damaskus: alAhali, 1990), 33. 
Amîn al-Khûlî, Manâhij al-Tajdîd fí al-Nahw wa al-Balâghah wa al-Tafsîr wa alAdâb. Beirût: Markaz al-Tsaqafî al-Arabî, 1961 M.

Abdul Mustaqim, Pergeseran Epistemologi Tafsir .Pustaka Pelajar, Yogyakarta, 2008.

Amin Al-Khulli dan Nasr Hamid Abu Zaid Metode Tafsir Sastra, ter. Khairon Nahdiyyin.Yogyakarta: Adab Press, 2004..

Bâqir al-Hakîm, 'Ulûm al-Qur'ân. Qum: Majma'e al-Fikr al- Islâmî, 1426 H.

Bâqir al-Shadr, al-Islâm Yaqûd al-Hayâh. Qum: Markaz al-Abhâts wa al-Dirâsât al-Takhashshushiyyah li al-Syahîdal-Shadr, 1979 M.

Fathul Mufid, Filsafat Ilmu Islam. Kudus: STAIN KUDUS, 2008.

Ghulen, Fathullah, Jihad Menegakkan Kalimat Allah, H. Ubaidillah (penerjemah), (Istambul: al-Zaman, $1996 \mathrm{M}$ )

Hendar Riyadi, TafsirEmansipatoris. Bandung, Pustaka Setia, 2005.

Nashr Hâmid Abû Zaid, Mafhûm al-NashshDirâsah fì 'Ulûm al-Qur'ân. Beirût: Markaz al-Tsaqafî al-Arabî, 1994 M.

Halliday dan Ruqayya Hasan, Bahasa, Konteks, dan Teks: Aspek-aspek Bahasa dalam Pandangan Semiotika Sosial. Yogyakarta: Gadjahmada University Press, 1994.

Hendar Riyadi, Tafsir Emansipatoris. Bandung, Pustaka Setia 2005.

Ibn Khaldûn, Muqaddimah IbnKhaldûn. Kairo: Makatabah al-Nahdhah alMishriyyah, $2001 \mathrm{M}$.

Hasan IbrâhîmHasan, Târîkh al-Islâmî: al-Siyâsî, al-Dîn̂, al-Tsaqafî, al-Ijtimâ' '̂,. Kairo: Makatabah al-Nahdhah al-Mishriyyah, $2001 \mathrm{M}$.

Kuntowijoyo, Paradigma Islam. Bandung: Penerbit Mizan, $1991 \mathrm{M}$.

J. Brugman, An introduction to History of Modern Arabic Literature in Egypt. Leiden: Ej Brill, $1984 \mathrm{M}$.

Khomeini al-Musâwî, Jihâd. Qum: Anshariyyan Publications, 1990 M.

M. Yunan Yusuf, "Karakteristik Tafsir al-Qur'an di Indonesia Abad Kedua puluh", Ulumul Qur'an, Vol.III, No.4, 1992.

M. Yunan Yusuf, "Karakteristik Tafsir al-Qur'an di Indonesia Abad Keduapuluh", Ulumul Qur'an, Vol.III, No.4, 1992

Muhammad Syahrur, al-Kitāb wa al-Qur'ān: Qirā'ah al-Mu'āṣirah. Damaskus: alAhali, 1990.

Nurcholish Madjid, dalam Budhy Munawar Rahman (editor), Kontekstualisasi Doktrin Islam dalam Sejarah, (Jakarta: Paramadina, 1995 M.

Syu'bah Asa, Dalam Cahaya al-Quran;ayat-ayat sosial politik, PT Gramedia. 1980 . 